\title{
INVESTIGATION OF BRAN LOAVES STALING FOR THE USE OF COMPLEX BAKING IMPROVER "FRESHNESS"
}

\author{
Olena Bilyk \\ Department of Technology of bakery and confectionery products \\ National University of food technologies \\ 68 Volodymyrska str., Kyiv, Ukraine, 01601 \\ bilyklena@gmail.com \\ Vira Drobot \\ Department of Technology of bakery and confectionery products \\ National University of food technologies \\ 68 Volodymyrska str., Kyiv, Ukraine, 01601 \\ v.i.drobot@ukr.net \\ Yulia Bondarenko \\ Department of Technology of bakery and confectionery products \\ National University of food technologies \\ 68 Volodymyrska str., Kyiv, Ukraine, 01601 \\ bjuly@ukr.net \\ Esma Halikova \\ Department of Technology of bakery and confectionery products \\ National University of food technologies \\ 68 Volodymyrska str., Kyiv, Ukraine, 01601 \\ esma7@ukr.net
}

\begin{abstract}
Elderly people's ration must necessarily include bakery, enriched with food fibers, of yesterday baking. To improve their quality and increase their storage life, the complex bakery improver (CBI) "Freshness" was elaborated. The base of the complex improver is beer powder, combined with lecithin, enzymatic preparation Betamalt $25 \mathrm{FBD}$, carboxymethyl cellulose, ascorbic acid. According to the results of research, the optimal dose of CBI "Freshness" in the recipe of bran loaves that is $2 \%$ of flour mass was established. The processes, connected with staling and loss of organoleptic and physical-chemical parameters of bran loaves at storage, were considered. The results of the study of free and bound water in products indicate that CBI "Freshness" use decreases osmotically bound water content that confirms the deceleration of brain loaves staling process. It was established, that CBI "Freshness" use decreases crumbling of bran loaves and increase their swelling comparing with products without it. The studies proved that at CBI "Freshness" use, the content of bisulphite bounding compounds increases comparing with a control at the expanse of the increase of the amount of substances, that form a smell at dough ripening and dough half-finished products baking. The increase of carbonyl compounds amount in bran loaves correlates with more intense flavor and smell of products, and with a crust coloration. The positive influence of CBI "Freshness" use on microbiological parameters was received that is proved by bran loaves storage life increase up to 72 hours. It was proved, that BCI "Freshness" use favors the increase of non-packed bran loaves storage life up to 72 hours at the expanse of osmotically bound water content decrease and microbiological pureness increase.
\end{abstract}

Keywords: staling process, complex bakery improver, crumbling, swelling, free and bound moisture, microbiological parameters, bisulphate bounding compounds.

\section{Introduction}

The speed of bakery staling depends on such factors as a recipe, technological process, sort and quality of flour, storage conditions and so on [1]

Bakery is most spread products in elderly and old people's food. Statistical data indicate that in $90 \%$ of cases of $100 \%$ digestion process in elderly worsens, so it is recommended to them to consume yesterday bakery instead of fresh one [2-4]. 
The solution of the problem of storage of bakery, enriched with food fibers is, in first turn, connected with the increase of its organoleptic and physical-chemical parameters [5]. Food additives or complex bakery improvers are used in bakery industry for this aim. The content of bakery improvers includes food additives of renewal, oxidizing effect, structure-creators, surface-active substances and enzymatic preparations [6].

The urgent direction of the solution of the problem of freshness prolongation of products, enriched with food fibers, is the elaboration of new complex bakery improvers, based on the joint use of non-traditional raw material and food additives. Beer protein is, for example, such non-traditional raw material.

\section{Materials and Methods}

The complex bakery improver (CBI) "Freshness", elaborated at the department of bakery and confectionary technologies of the National University of food technologies (Ukraine), consists of beer powder, combined with lecithin, enzymatic preparation Betamalt $25 \mathrm{FBD}$, carboxymethyl cellulose, ascorbic acid. Beer powder was produced of beer proteins, received by aged beer filtration through diatomite, membrane or other filters [7]. Bran loaves were produced of wheat flour of the senior quality by the leaven method by the recipe:

- wheat flour of the senior quality $-80 \mathrm{~kg}$;

- wheat bran - $20 \mathrm{~kg}$;

- bakery pressed leaven - $1,0 \mathrm{~kg}$;

- food salt - 1,2 kg;

- white crystalline sugar $-0,5 \mathrm{~kg}$.

For the study of technological process parameters, biochemical, physical-chemical changes in dough and bread qualitative parameters, the laboratory baking was realized. Dough was prepared by the leaven method with the leaven moisture mass share $-42 \%$. Dough was mixed in the two-speed dough-mixing machine. The complex bakery improver was dosed in dry form at dough mixing in amount 1,$0 ; 1,5 ; 2,0 ; 2,5$ and $3,0 \%$ of flour mass. Dough half-finished products were prepared by hand. They were kept at the temperature $(35 \pm 2){ }^{\circ} \mathrm{C}$ and relative humidity $(75 \pm 2) \%$ up to the readiness. Products were baked in the oven at the temperature $220 \ldots .240{ }^{\circ} \mathrm{C}$. The studied samples of wheat bread were stored at the temperature $(20 \pm 2){ }^{\circ} \mathrm{C}$ and relative humidity $(75 \pm 2) \%$. The assessment of quality was realized in 4, 24, 48 and 72 hours after baking.

Bread quality was assessed by physical-chemical (specific volume, form steadiness, structural-mechanical properties of crumb) and organoleptic parameters (appearance, state of crust surface, porosity structure, flavor, smell). The term of keeping freshness by products was studied by changes of crumb structural- mechanical properties. Its general deformation was determined after 72 hours of storage on the penetrometer AP 4/1 ("Finemass" (Germany). The complex quality parameter was assessed by the point scale of bakery quality that includes most essential quality parameters - specific volume, form accuracy, crust color, crumb deformation after 72 hours of storage, crumbling, form steadiness, state of crust surface, crumb color, porosity structure, crumb rheological properties, flavor, smell, chewing degree) [8].

A degree of products staling was studied also by bran loaves crust swelling and crumbling. The more dry bread, the less crumb swelling is. Staling degree is expressed by the value of specific swelling in $\mathrm{cm}^{3}$ of swelled mass for $1 \mathrm{~g}$ of the dry substance of the studied sample [9]. Crumbling was assessed by crumbs creation as a result of rubbing of two pieces of bread with mass $5 \mathrm{~g}$, cut in parallelepiped form as a result of shaking them off during $5 \mathrm{~min}$ on the vibration shaker IKA HS 501 digital (IKA ${ }^{\circledR}$-Werke GmbH \& Co. KG (Germany)). Crumbling was expressed as a ratio of crumb mass to bread batch mass in percents.

Changes of moisture bounding form in bakery crumb during its storage was assessed by the thermographic method of bound moisture study on the derivatograph Q-1500 (MOM system firm of Paulik-Paulik-Erdey (Hungry)) in the temperature diapason $20-200{ }^{\circ} \mathrm{C}$. The essence of this method is in fact that the sample and standard are loaded in the working chamber and heated with the permanent speed. At that the sample temperature is measured and the difference between temperatures of the sample and standard is continuously registered using the differential thermo- 
couple. In parallel with temperature measurements of the work and standard samples, their mass is controlled. Moisture removing takes place at heating and it results in the decrease of the sample mass [9].

The content of aromatic substances in bran loaves was assessed by the amount of bisulphate compounds [10]. This amount is grounded on the ability to bound aldehydes and several ketones by sodium bisulphate creating adducts. This method is based on the preliminary removal of non-reacted bisulphate by iodine with further destruction of adducts by sodium bicarbonate and titration of released bisulphite, equivalent to the content of carbonyl compounds.

The determination of side and harmful microflora in ready products was realized by standard methods [11].

The processing of the experimental studies results were realized using methods of statistical calculation of measurement results reliability. Approximations of empirical data were realized using e-tables MSExcel 2010.

\section{Results}

According to the point scale, it was established that the most complex quality rate is inherent to bran loaves with introduction of $2 \%$ of CBI "Freshness" to four mass. On the Fig. 1 are presented bran loaves with different doses of CBI "Freshness".

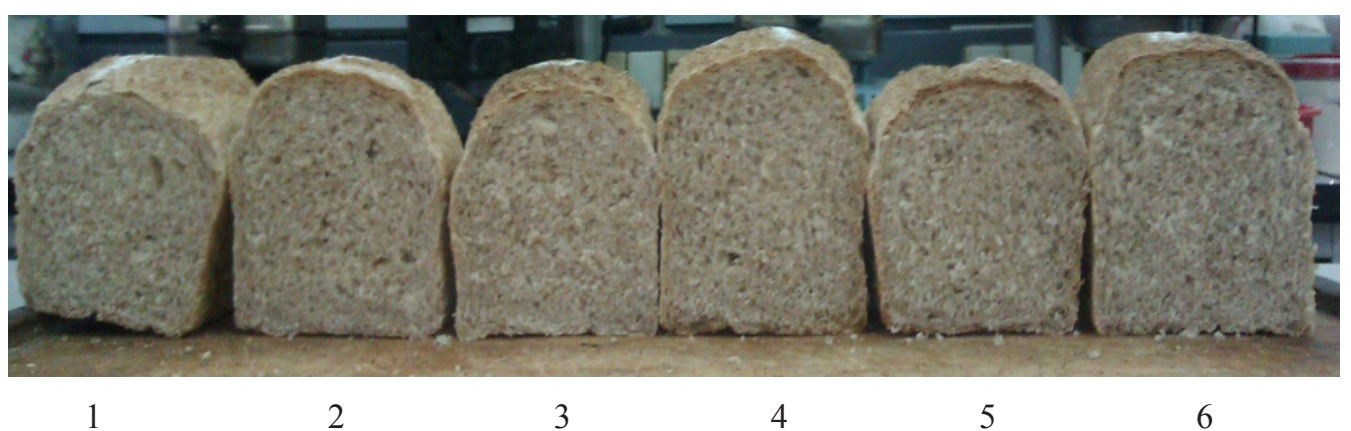

Fig. 1. Bran loaves: 1 - control without additives; 2 - with 1,0 \% of CBI "Freshness" to flour mass; 3 - with $1,5 \%$ of CBI "Freshness" to flour mass; 4 - with 2,0 \% of CBI "Freshness" to four mass; 5 - with 2,5\% of CBI "Freshness" to flour mass; 6 - with 3,0 \% of CBI "Freshness" to flour mass

In the process of bran loaves storage, the crumbling rate increases. The results of the studies indicate that the crumbling rate of bran loaves at using CBI "Freshness" decreases comparing with the control - by $38,9 \%$ at storage during 24 hours, by $46,9 \%-48$ hours and by $48,3 \%-72$ hours.

The decrease of colloid substances ability to absorb water at the expanse of starch and proteins structure compression in the process of their ageing conditions the decrease of crumb swelling [9]. Water bounding by crumb of products in both control ones and with CBI "Freshness" decreases at storage. The decrease of this rate at 3 day of storage was $29,6 \%$, comparing with the control $(39,2 \%)$, that testifies to the deceleration of hydrocolloids ageing in products.

At the same time products freshness preservation was studied by the change of the under-crust layer. The assessment was realized organoleptically. It was noted, that in the sample with CBI "Freshness" after 72 hours of storage the under-crust layer was less than in the control one and correspondingly had more crumb without staling signs (Fig. 2).

The processing of the thermographic analysis results demonstrates that the moisture loss for the control sample in 1 day of storage is $23,3 \%$ of the general mass of moisture in loaves, in the samples with CBI "Freshness"- 21,67 \%. On 4 day of products storage, the content of moisture of these forms of bounding in products with CBI "Freshness" doesn't change relative to the general water mass in bran loaves, and in the control it decreases by 2,63\%. The amount of osmotically bound water in samples with CBI "Freshness" is higher relative to the control sample both after first and fourth day of storage. The amount of adsorptionally bound water at storage increases both in the control and in samples with CBI "Freshness". 


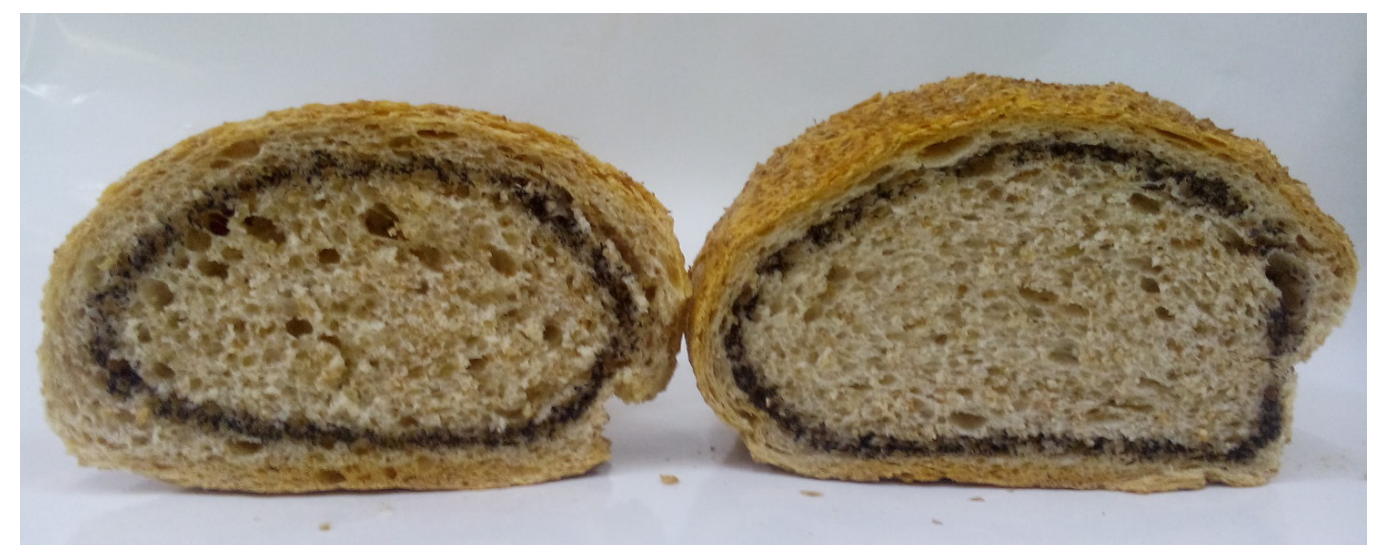

1

2

$a$

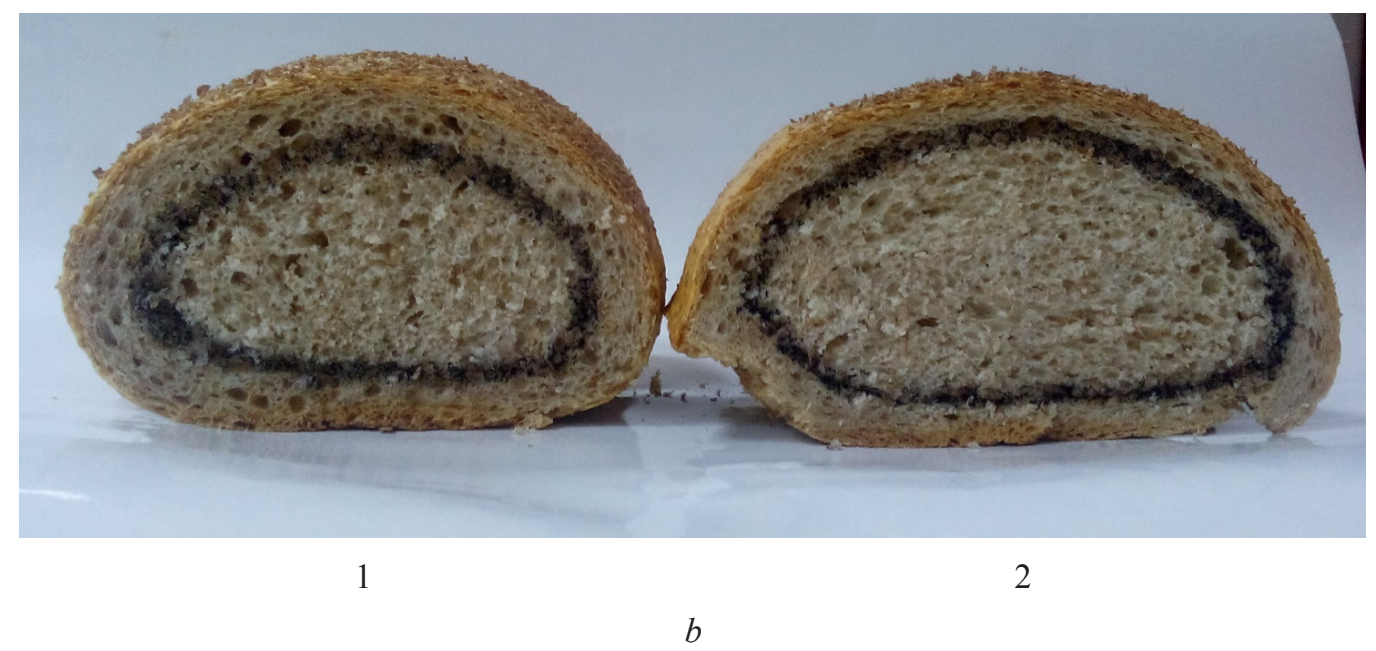

Fig. 2. Changes of under-crust layer of bran loaves at storage:

1 - control without additives; 2 - with CBI "Freshness" 2,0 \% to flour mass; $a$-after 4 hours of storage; $b$ - after 72 hours of storage

It is known [12] that flavor and smell depend on products of sugars and carbonyl compounds interaction with amino acids and proteins. The study of carbonyl compounds content by the amount of bisulphate compounds demonstrated that bisulphate compounds content increases in $1,8 \ldots 2,1$ times comparing with the control. It is explained by the increase of the amount of substances that form a smell at dough ripening and dough half-finished products baking. The addition of CBI "Freshness" favors better preservation of aromatic substances both in crumb and in crust of the studied sample comparing with the control.

After baking a crust of bakery is almost sterile but a crumb center is heated to the temperature $93 \ldots 98^{\circ} \mathrm{C}$, so some amount of bacterial spore and vegetative cells remain in a crust $[11,13]$.

It is noted, that at storage of studied samples during 72 hours, NMAFAM in them is less comparing with the control, and the amount of mould fungi increases but remains within permissible norms that gives grounds to store bran loaves during 72 hours.

\section{Conclusions}

In the result of the studies the optimal dose of CBI "Freshness" in bran loves baking was established $-2 \%$ of flour mass.

The study of bound and free water content in bran loaves, crumbling and swelling rates and microbiological parameters proves the positive influence of CBI "Freshness" use in the optimal 
dose to prolong the freshness preservation up to 72 hours at the expanse of the decrease of osmotically bound water content and increase of microbiological pureness.

Thus, the received results demonstrate the expedience of CBI "Freshness" use in bran loaves technology to prolong freshness preservation up to 72 hours. The prolongation of bran loaves storage life allows to widen the assortment of products for elderly. Further studies on this subject will be realized in the direction of investigation of CBI "Freshness" influence on structural-functioning properties of dough and industrial approbation.

\section{References}

[1] Kylkast, D., Subramanyam P. (Ed.). (2012). Stabylnost y srok hodnosty. Khlebobulochnye y kondyterskye yzdelyia. Saint Petersburg: Professyia, 444.

[2] Drobot, V. I. (Ed.). (2016). Innovacijni tehnologiyi diyetychnyh ta ozdorovchyh hliboublochnyh vyrobiv. Kyiv: Kondor-Vydavnycztva, 238.

[3] Kennet, F. F., Wilmonth, J. M. (2013). Gerontology: perspectives and issues. Springer Publishing Company, 384.

[4] Pray, L., Boon, C., Miller, E. A., Pillsbury, L. (2010). Providing Healthy and Safe Foods As We Age. Washington: The national academies press,192. doi: 10.17226/12967

[5] Kalynyna, Y. V., Naumenko, N. V., Feklycheva, Y. V. (2015). Yssledovanye kachestva obohashchennыkh vydov khleba v protsesse khranenyia. Vestnyk YuUrHU. Seryia «Pyshchevye y byotekhnolohyy», 3 (1), 36-44.

[6] Bairamov, Je. Je. (2014). Uluchshytely, ponyzhaiushchye elastychnost y povyshaiushchye rastiazhymost kleikovyny y testa. Kharchova nauka i tekhnolohiia, 4 (29), 70-76.

[7] Bilyk, O., Halykova, E., Marynin, A., Zakharevych, V. (2014). Beer powder - unconventional materials to extend the shelf life of baked goods. Scientific works of university of food technologies, LXI, 14-19.

[8] Lebedenko, T. Ie., Pshenyshniuk, H. F., Sokolova, N. Iu. (2014). Tekhnolohiia khlibopekarskoho vyrobnytstva. Odesa: «Osvita Ukrainy», 392.

[9] Drobot, V. I. (2015). Tekhnokhimichnyi kontrol syrovyny ta khlibobulochnykh i makaronnykh vyrobiv. Kyiv: NUKhT, 902.

[10] Reuben, B., Coultate T. (2009). On the rise. Chemistry World, 10, 54-57.

[11] Hrehirchak, N. M. (2009). Mikrobiolohiia kharchovykh vyrobnytstv. Laboratornyi praktykum. Kyiv: NUKhT, 302.

[12] Chubenko, N. T., Chereda V. V. (2008). Vkus y aromat - vazhnye faktory vozdeistvyia na eho potreblenye. Khlebopechenye Rossyy, 4, 24-26.

[13] Gerez, C. L., Torino, M. I., Rollán, G., Font de Valdez, G. (2009). Prevention of bread mould spoilage by using lactic acid bacteria with antifungal properties. Food Control, 20 (2), 144-148. doi: 10.1016/ j.foodcont.2008.03.005 